DOI: https://doi.org/10.24867/08FA16Apostolovic

\title{
PRISTUP PROJEKTOVANJU SAVREMENIH JAVNIH PROSTORA MALE RAZMERE U NOVOM SADU
}

\section{APPROACH TO THE DESIGN OF SMALL PUBLIC SPACES IN NOVI SAD}

\author{
Nataša Apostolović, Fakultet tehničkih nauka, Novi Sad
}

\section{Oblast - ARHITEKTURA I URBANIZAM}

Kratak sadržaj- Problematika istraživanja smeštena je $u$ kontekst konstantnih promena na svim poljima savremenog života. Ispituje se kapitalistički društveni sistem u čijem okviru nastaje potrošački mentalitet, kao i sredstva poput masovnih medija, kojima sistem utiče na članove društva. Akcenat je na uticaju ovakvih okolnosti na projektovanje $i$ kvalitet javnih gradskih prostora. Kao moguće rešenje za pitanje savremenih javnih prostora, rad predstavlja projektantski pristup koji teži da ukaže na značaj raznovrsnih, kvalitetnih $i$ sadržajnih javnih prostora na lokalnom nivou, koji su autentični i nekomercijalni.

Ključne reči:, globalizacija, konzumerizam, javni prostor

Abstract- The research issue takes place in the context of constant changes in all the fields of contemporary life. It examines the capitalist social system within which the consumer mentality is created, as well as the means such as mass media, by which the system influences the members of society. Emphasis is placed on the impact of such circumstances on the design and quality of public spaces. As a potential solution to the issues of contemporary public spaces, this paper presents an urban design approach that seeks to highlight the importance of diverse, high quality, content-based public spaces that are authentic and non-commercial.

Ključne reči: globalization, consumerism, public space

\section{UVOD}

Termin globalizacija, uspostavljen sedamdesetih godina prošlog veka, odnosi se pre svega na ekonomsko-političke promene u svetu, a zatim i na sociološke i kulturološke translacije, koje su dovele do značajnog povećanja internacionalne razmene. U najširem smislu, ovaj pojam odnosi se na drastično povećanu slobodu kretanja robe, ideja i ljudi od kraja XX veka.

Paradigma potrošačkog društva koje karakteriše zajednicu na globalnom nivou jedan je od najznačajnijih fenomena savremenog sveta. Konzumerizam i pojava novih medija, koju je uslovio razvoj tehnologija, učinili su da se svetska ekonomija zasniva na daleko bržim i frekventnijim interakcijama nego ikad ranije. Ono što karakteriše ove kompleksne procese jeste fenomen homogenizacije kulturnog nasleđa i društva kao globalne zajednice [1].

\section{NAPOMENA:}

Ovaj rad proistekao je iz master rada čiji mentor je bila dr Milica Vračarić, vanr. prof.
Istraživanje se bavi uspostavljanjem veze između konzumerske kulture podstaknute uticajem masovnih medija i kulturološke homogenizacije. Tematika je smeštena $u$ kontekst globalizovanog društva, koje je u procesu digitalizacije zanemarilo fizički kontekst, a samim tim i kulturološke, istorijske i druge različitosti. Problemi megalomanije i globalizacije stavova o javnom prostoru obrađeni su kroz sistematično razdvajanje vrsta javnih prostora, sa akcentom na tvrdnji da se pitanje kvaliteta javnih prostora ne može generalizovati.

Cilj ove teze je da ukaže na značaj decentralizacije javnog sadržaja i njegovog posmatranja na lokalnom nivou, kako bi se unapredio kvalitet života $\mathrm{u}$ savremenim gradovima. Naglašava se potreba za funkcionalnom raznovrsnošću javnih prostora, njihovih korisnika i konteksta. Rad predstavlja tri konkursna rešenja koja se bave malim javnim prostorima u Novom Sadu i njegovim prigradskim naseljima. Rešenja su izabrana na osnovu projektantskog pristupa koji ih objedinjuje i koji nudi humaniji stav prema dizajnu javnog prostora u savremenom kontekstu.

\section{TEORIJSKI OKVIR ISTRAŽIVANJA}

\subsection{Globalizacija}

Globalizacija se definiše kao prihvatanje skupa ekonomskih pravila koja se odnose na ceo svet, a čija svrha je da maksimiziraju profit i produktivnost univerzalizacijom tržišta i proizvodnje. Ovaj proces se vezuje za prelazak sa industrijskih na postindustrijska društva, pri čemu je došlo do niza međusobno uslovljenih pojava na društvenoj i ekonomskoj sceni. U trenutku ove tranzicije između dva sistema došlo je do krize nekadašnjih privrednih giganata, odnosno do potpune promene njihovih međusobnih odnosa na svetskom tržištu [2].

Karakteristika prve faze globalizacije je prividno uravnotežavanje nekadašnje tržišne hijerarhije, kao i ubrzana razmena robe $\mathrm{u}$ fizičkom smislu $\mathrm{u}$ drugoj polovini XX veka.U ovom periodu javljaju se i pojmovi transnacionalne geografije i politike [3]. Drugu fazu karakteriše rapidan naučno-tehnološki razvoj, koji više nije usmeren na unapređenje industrijske proizvodnje, već se ova faza naziva digitalizacija. Od primarnog značaja postala je virtuelna roba (data). Ovo je period znatno olakšane međunarodne komunikacije na svim nivoima, za šta je zaslužna pojava interneta.

\subsection{Kulturolološka i prostorna homogenizacija kao posledica digitalne globalizacije}

U trenutku kada su gotovo uklonjene jezičke barijere i pri olakšanoj komunikaciji putem interneta, stvara se utisak 
da je svet zaista postao globalna zajednica. Ova pojava uslovila je da se korisnicima u svim delovima sveta plasiraju iste ,potrebe“, proizvodi i sadržaji. Čovečanstvo se često posmatra kao zajednica kojoj je moguće pristupiti univerzalnim sredstvima i rešenjima.

\subsection{Konzumerizam i uticaj masovnih medija}

Masovna proizvodnja i masovna tržišta, uz propagandu masovnih medija uslovili su potrošačku kulturu XXI veka. Kako se društvena hijerarhija značajno izmenila u poslednjih 100 godina, sve je veći broj ljudi u takozvanoj potrošačkoj, odnosno srednjoj klasi. Značajna osobina koja opisuje konzumersku kulturu je da se sve posmatra kao roba. Ne radi se samo o artiklima, odnosno opipljivoj robi, već i o doživljajima, atrakcijama i iskustvima koji se svakodnevno konzumiraju.

Pojava brendiranja vezuje se upravo za razvoj konzumerske kulture kada nastaju globalni brendovi koji i danas dominiraju tržištem [4]. Jedan od najvećih faktora koji utiču na razvoj potrošačkih društava jesu masovni mediji koji propagiraju stav da sreća i zadovoljstvo pojedinca zavise od toga koliko poseduje. Isto tako, mediji plasiraju uvek nove, površne potrebe, za koje potom nude određena rešenja. Prisustvo masovnih medija onemogućilo je stvaranje subjektivnih, ali i potpuno objektivnih stavova, jer konstantno prikazuje filtrirane slike realnosti.

\section{3. ŠTA JE JAVNI PROSTOR DANAS?}

\subsection{Problemi savremenih javnih prostora}

$\mathrm{U}$ fokusu rada je sagledavanje problema koncipiranja javnih prostora $\mathrm{u}$ kontekstima koji su razmatrani $\mathrm{u}$ teorijskom okviru istraživanja. Bavi se pitanjima sadržaja, funkcije i pristupa projektovanju javnih prostora, kao i njihovih odnosa prema okolini i korisnicima. Ovo je problem ne samo društvenog, ekonomskog ili tehničkog, već humanog karaktera, jer je sve teže za korisnike da se identifikuju sa gradskim prostorom.

Savremeni javni prostori često su koncipirani tako da je njihov sadržaj pretežno komercijalan, odnosno da ih korisnici na neki način konzumiraju. Sociološka homogenizacija uslovila je pojavu da fizička lokacija korisnika ne utiče mnogo na njegovo poimanje javnog prostora, jer se njegova banalizovana slika na isti način plasira u celom svetu.

Još jedan problem javlja se sa činjenicom da se javni sadržaj mahom centralizuje i okuplja oko žižnih tačaka u naseljima, dok su periferni delovi i prigradska naselja gotovo potpuno zapostavljeni.

\subsection{Razmatranje javnog prostora: mikro i makro, lokalno i globalno}

Pri razvrstavanju javnih prostora na male i velike, posmatra se njihov gabarit, dok je kriterijum za lokalne odnosno globalne javne prostore - polje uticaja istih. Pojava megalomanije uticala je u velikoj meri i na projektovanje gradskih prostora. U slučaju predimenzionisanih građevina $\mathrm{i}$ javnih prostora, nameće se određena vrsta strahopoštovanja korisnika prema okolini. Veliki prostori imaju dosta prednosti u smislu kapaciteta i dodavanja prostornih elemenata, ali se postavlja psihološko pitanje doživljaja takvih prostora u odnosu na one manje, koje korisnici vide kao intimnije, sigurnije i neformalnije.

Pitanje lokalnog i globalnog javnog prostora preispituje se kroz primere koji nisu uvek u fokusu razmatranja, a to su periferni, „nepristupačni““ javni prostori od lokalnog značaja.

\subsection{Javni prostori potrošačke kulture - tržni centri kao ekstrem}

Arhitektonska tipologija koja najslikovitije opisuje potrošačko društvo je tipologija tržnih centara. Objekti tržnih centara nastali su kao direktan odgovor na težnje društva da svoje slobodno vreme posvećuje potrošnji, odnosno konzumiranju. Oni su projektovani kako bi se u njima obrtao kapital i u potpunosti su prilagođeni konzumerskom mentalitetu.

Svi sadržaji tržnih centara osmišljeni su tako da privuku što veći broj korisnika i da im nametnu što duži boravak. Ono što ovu tipologiju direktno vezuje za pojam globalizacije jeste što je u vrlo kratkom periodu postala rasprostranjena u celom svetu. Tržni centri su ekstrem po pitanju savremenog shvatanja javnog prostora, $u$ potpunosti zanemarujući kontekst u kome se nalaze.

\section{PRISTUP PROJEKTOVANJU SAVREMENIH JAVNIH PROSTORA KROZ PRIMERE KONKURSNIH REŠENJA ZA KONKURS ,NOVA MESTA“ - KONKURS ZA DIZAJN MALIH JAVNIH PROSTORA U NOVOM SADU}

Novi projektantski pristup ponuđen je kao moguće rešenje za probleme javnih prostora koji nastaju $\mathrm{u}$ istraživanom kontekstu. On treba da dovede do rešenja koja će biti humanijeg karaktera, raznovrsnog i nekomercijalnog sadržaja.

Ovaj pristup projektovanju javnih prostora u fokus stavlja značaj konteksta (arhitektonskog, geografskog, kulturnoistorijskog) u okviru kog se deluje. Profil trenutnih i potencijalnih korisnika se detaljno analizira, čime se ne ostavlja prostor za univerzalna, generička rešenja.

\subsection{Konkurs „Nova Mesta“}

Raspisom ovog konkursa skreće se pažnja javnosti na problem nedostatka manjih, funkcionalno i kontekstualno različitih javnih površina na prostoru grada Novog Sada i njegovih prigradskih naselja. Cilj konkursa je da se postojeće javne površine reanimiraju ili osposobe i dobiju nov karakter u skladu sa svojim kontekstom i da doprinesu tome da Novi Sad opravda titulu Evropske prestonice kulture za 2021.godinu.

\subsection{Participacija građana - prepoznavanje konkretnih problema, sužavanje prostornog okvira i ukazivanje na potrebe i potencijale određenog prostora}

Značajna karakteristika konkursa jeste što potencira aktivno učešće građana u prepoznavanju kako postojećih kritičnih tačaka u njihovom životnom okruženju, tako i potencijala ovih prostora. Participacija se realizuje putem anketiranja građana, a potom razgovorima u okviru fokus grupa. 


\subsection{Projektantski pristup pri osmišljavanju konkursnih rešenja malih javnih površina}

Svako od rešenja vodilo se projektantskim pristupom koji teži da reši neke od problema savremenih javnih prostora kojima se rad bavi. Cilj projekata bio je stvaranje autentičnih prostora raznolikog funkcionalnog karaktera koji u najvećoj mogućoj meri odgovaraju potrebama korisnika. Jednostavnost je bila i cilj i sredstvo u procesu projektovanja sva tri rešenja.

Takođe, radovi teže da ukažu na značaj i potencijale malih javnih prostora u gradu i prigradskim naseljima. Svakom projektu pristupano je kao karakterističnom zadatku u okviru iste, šire problematike.

Projektantski pristup pri rešavanju svake od lokacija Bukovac, Begeč i Salajka može da se svede na neke od osnovnih principa kojima se tim vodio, a to su:

1. Kontekst (prostorni, istorijski, sociološki)

2. Korisnici

3. (Multi)funkcionalnost

4. Ekonomičnost

5. Atraktivnost

\subsection{Projektantski pristup obrazložen kroz tri konkursna rada za lokacije Bukovac, Begeč i Salajka}

\subsubsection{Projekat trga sa multifunkcionalnih elementom} urbanog mobilijara u mesnoj zajednici Bukovac

Projektni zadatak za ovu lokaciju naglašavao je potrebu za transformabilnim javnim prostorom. Značajna smernica bila je konstatacija građana prisutnih na fokus grupama da je za Bukovac značajan lik pesnikinje Milice Stojadinović Srpkinje, kao i da postoje kulturna i sportska udruženja bez adekvatnih prostorija za aktivnosti.

U obzir je pre svega uzet kulturno istorijski kontekst, kao i prostorni, budući da se lokalitet nalazi u ruralnom naselju. Početna tačka pri prostornoj artikulaciji bila je činjenica da je korisnicima potreban prostor za okupljanje. Najdominantiji element je mobilijar koji se pruža duž Ulice Kralja Petra I i vrši nekoliko funkcija kao što su zaštita korisnika od saobraćaja i sedenje.

Element je kombinovan sa visokim i srednjim rastinjem koje upotpunjuje ambijent novoprojektovanog trga. U znak sećanja na poznatu srpsku pesnikinju, parterno uređenje ima funkciju održavanja i promovisanja lokalnog identiteta naselja.

U nekima od ploča ugravirani su stihovi Milice Stojadinović i na taj način skreću pažnju na kulturno-istorijski značaj lokacije. Postojeća česma koja je bila fokus lokacije zamenila se novom, modernog dizajna.

Rezultat ovakvog koncipiranja javnog prostora u Bukovcu jeste da njegovi elementi deluju kao celina, a dozvoljavaju transformacije koje su potrebne za aktivnosti budućih korisnika.

Takođe, podiže se svest meštana o značaju njihovog naselja i time podstiče aktivno učešće $\mathrm{u}$ daljem unapređivanju njegovog prostora.

Na Slici 1. prikazan je deo ambijenta novoprojektovanog trga, na kome je jasan odnos mobilijara, okolne saobraćajne infrastrukture i slobodnog platoa.

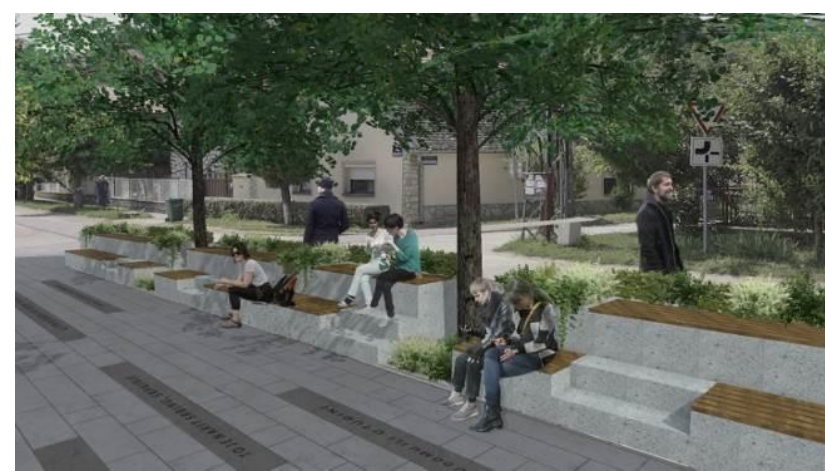

Slika 1. Prostorni prikaz novoprojektovanog rešenja u Bukovcu

\subsubsection{Projekat uređenja dvorišta kulturnog centra u} Begeču

Za ovu lokaciju bilo je potrebno ponuditi rešenje koje će omogućiti da se prostor koristi u toku celog dana. On treba da bude okvir za boravak korisnika, kao i za različite aktivnosti koje mogu, a ne moraju biti u vezi sa radom Kulturnog centra „Begeč“. U najvećoj meri razmatrani su arhitektonski i funkcionalni kontekst, zbog fizičke ograničenosti lokacije. Bilo je potrebno da nova struktura bude nenametljiva i jednostavna, kao i da generiše nove načine upotrebe prostora. Multifunkcionalnost je u tom smislu najsnažnija karakteristika ovog projekta. Takođe je uzeto u obzir isticanje meštana da je Begeč poznat po uzgoju šargarepe. Projekat je koncipiran na jednostavan način, sadržeći dve vrste elemenata koji funkcionišu kao celina: šine i pomerljivi kubusi namenjeni za sedenje, stvaranje bine i igru.

Rezultat je da korisnici sami određuju trenutnu funkciju prostora i prilagođavaju ga svojim željama i potrebama. Takođe, ispoštovane su i potrebe kulturnog centra za prostorom na kome će se održavati manifestacije i okupljanja, s obzirom na to da je moguće od mobilijara napraviti binu. Na suptilan način se aludira na autentičnu osobinu ovog naselja tako što su određeni elementi mobilijara narandžaste boje. Dvorište kulturnog centra poprima autentičan, inovativan i atraktivan izgled.

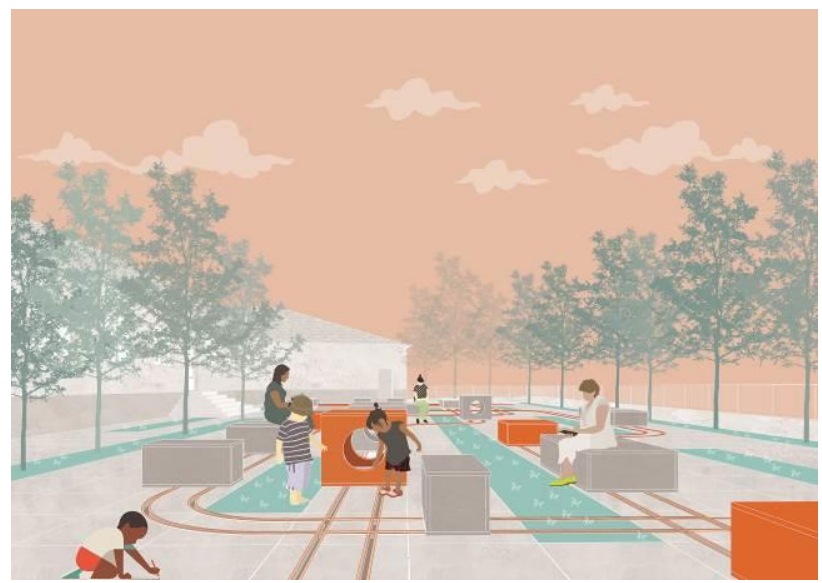

Slika 2. Prostorni prikaz novoprojektovanog rešenja u Begeču

S1.2. prikazuje različite načine upotrebe jednostavnog mobilijara. Pošto je on pomerljiv, korisnici lako mogu da stvaraju nove ambijente i mikroambijente u zavisnosti od 
potreba i želja. Takođe je prikazana i varijanta mobilijara koja služi za dečiju igru.

\subsubsection{Projekat savremenog igrališta i sportskog terena na Salajci}

Projekat na Salajci trebalo je da reši problem neiskorišćene zelene površine pored kompleksa Sportskog centra „Slavija“. Mesnoj zajednici nedostaju sadržaji koji prate funkciju ovog kompleksa, kao i prostori za okupljanje, odmor i opuštanje. Meštani su istakli da bi Salajka trebalo da dobije autentičan prostor kakav ne postoji u drugim delovima grada.

Od velikog značaja za postavljanje koncepta bio je istorijski kontekst koji se povezao sa funkcionalnim. Jedan od poznatih Salajčana bio je fudbaler Svetozar Toza Veselinović. Upravo njegov lik poslužio je kao inspiracija za osmišljavanje parternog uređenja ovog prostora, koji ga čini neobičnim i atraktivnim zahvaljujući modernom dizajnu.

Kao rezultat ovakvog idejnog rešenja javlja se funkcionalna određenost čitavog dela naselja, čime ono postaje atraktivno i za nove korisnike. Kako je sport od velikog značaja za meštane Salajke, bitno je bilo podstaći ovu činjenicu i naglasiti autentičnost lokacije. Osim što je estetski specifičan, projekat neuobičajenim sadržajem podstiče kreativnost korisnika, a pogotovo dece. Projekat podstiče zalaganje građana za sport, rekreaciju i kvalitetno provođenje slobodnog vremena.

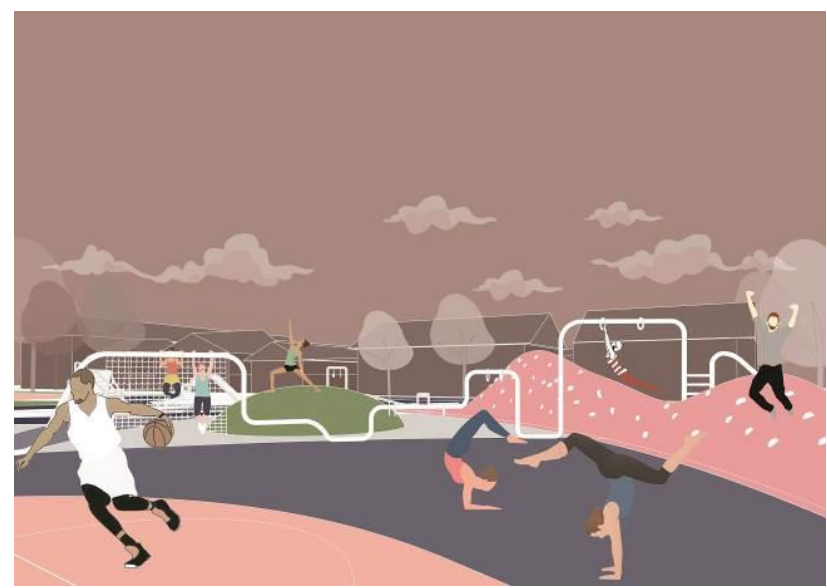

Slika 3. Prostorni prikaz novoprojektovanog rešenja na Salajci

Slika 3. predstavlja raznolikost sadržaja i mogućnosti upotrebe sprava i mobilijara na igralištu. Akcenat je na aktiviranju različitih grupa korisnika koji će na različite načine doživljavati i upotrebljavati ovaj prostor.

\section{ZAKLJUČAK}

Istraživanje pojava savremenog sveta kao što su globalizacija, potrošačka kultura i sociološko i kulturološko izjednačavanje društava poslužilo je kao okvir za sagledavanje javnih prostora u savremenom kontekstu i mogućnosti njihovog ponovnog promišljanja.
U velikoj meri je javni prostor, kao nosilac paradigme savremenih društava, postao jasna slika konzumerske kulture XXI veka.

Izgubila se humana uloga javnih prostora, kao i njihova autentičnost, budući da se uvek potencira ideja globalnih društava koja imaju iste potrebe. Kao ekstrem, javila se tipologija tržnih centara, koji kao jedinu interakciju iniciraju robno-novčanu razmenu.

Neophodno je ponovno promišljanje javnog prostora i njegovih društvenih funkcija. Prvenstveno je potrebno korigovati shvatanje potrebe za diverzitetom među vrstama javnih prostora, po pitanju gabarita, funkcije, konteksta i njegovih korisnika. Kako se ne bi upalo u zamku generalizovanja javnih prostora, pre svega treba izbegavati generalizovanje njihovih korisnika.

Oni treba da budu prilagođeni grupi ljudi koji će ga upotrebljavati. Ovo ne znači da gradovima nisu potrebni javni prostori od globalnog značaja, reprezentativni i u određenoj meri komercijalni, već da je za kvalitet savremenog društvenog života od suštinskog značaja postojanje lokalnih, autentičnih javnih prostora sa kojima se korisnici identifikuju. Kvalitet javnog prostora se meri odnosom ljudi prema njemu i aktivnim učešćem $u$ njegovom unapređivanju i razvoju.

\section{LITERATURA}

[1] Albrow, M.; King, E.:Globalisation, knowledge and society: readings from International sociology, Sage Publications, London, United Kingdom, 1990., 95

[2] Sassen, S.: The Global City: New York, London, Tokyo, Princeton University Press, New Jearsey, USA, 1991., 18

[3] Sassen, S.: Seeing like a city, 280

[4] Trandafilović, I.; Radonjić, A.; Filipović, T.: Karakteristike i posledice potrošačkog društva Zaječar, Fakultet za menadžment Zaječar, 2015., 81

\section{Kratka biografija:}

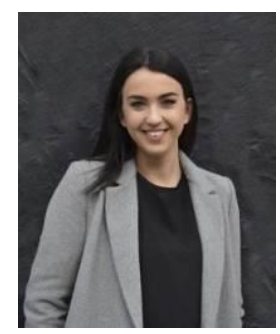

Nataša Apostolović rođena je $u$ Bačkoj Topoli 1995. godine. Master rad odbranila je 2019. godine na Fakultetu tehničkih nauka iz oblasti: Arhitektura i urbanizam- Urbanističko projektovanje. 